\title{
PENGUKURAN EFISIENSI ASURANSI SYARIAH DENGAN DATA ENVELOPMENT ANALYSIS (DEA)
}

\author{
Hulwah Tuffahati, Sepky Mardian dan Edy Suprapto \\ Program Studi Akuntansi Syariah \\ Sekolah Tinggi Ekonomi Islam SEBI \\ Email: sepky.mardian@gmail.com dan hulwah.thewinner@gmail.com
}

\begin{abstract}
This research is aimed to measure the efficiency of Islamic Insurance Companies in Indonesia by using Data Envelopment Analysis (DEA). The sample used in this research are the Islamic Insurance Companies that publishes their full financial statements from the years 2012-2014. The variables in this study consists of two kinds of variables, namely input variables and output variables. The variable input is the total assets and the cost of commissions. While the variable output is the gross contribution and investment income. This study uses the intermediation approach with input orientation and use three types of measurements are the measurement of the efficiency of technical efficiency, pure technical and scale. The results of this study are in the groups of Islamic General Insurance Companies and Islamic Life Insurance Companies there are no company that achieve optimal efficiency levels in the three types of measurements. Whereas in the group Syariah General Insurance Unit are 2 companies optimally efficient in 3 measurements or by $28.57 \%$ of the total companies sampled in this group. And the group Syariah Life Insurance Unit are 4 companies optimally efficient in 3 measurements or $25 \%$ of total companies sampled in this group.
\end{abstract}

Keywords: level of efficiency, Islamic insurance companies, financial statements, DEA.

\section{PENDAHULUAN}

Manusia merupakan makhluk sosial yang tidak bisa hidup seorang diri. Maka dari itu kehidupan manusia selalu bergantung kepada orang lain, apalagi dalam hal kegiatan ekonomi. Kondisi perekonomian di dunia selalu berubah dari keadaan awal yang aman hingga terjadinya krisis ekonomi. Krisis bukan hanya terjadi pada negara maju saja, akan tetapi terjadi juga di Negara berkembang. Seperti yang dialami Indonesia pada tahun 1998, dimana di negara tersebut terjadi krisis moneter yang mengakibatkan instansi keuangan mengalami kegoyahan bahkan tidak sedikit bank di Indonesia mengalami collapse. Namun, dari seluruh bank yang ada di Indonesia hanya bank dengan berbasis syariah yang mampu bertahan dari krisis yaitu Bank Muamalat Indonesia. Meskipun bank tersebut baru berusia 6 tahun (Febrinol, 2012).

Sejak terjadinya krisis tahun 1998, berbagai instansi keuangan mulai memperhatikan dan tertarik kepada ekonomi syariah yang diterapkan oleh Bank Muamalat. Sehingga di abad ke 20-an lembaga keuangan syariah pun 
mulai berkembang, baik bank maupun non bank terbukti hingga saat ini sudah ada asuransi syariah, pegadaian syariah, pasar modal syariah, dan sebagainya. Dan sejak itulah topik mengenai ekonomi syariah menjadi perbincangan yang hangat, sekaligus menunjukkan bahwa masyarakat Indonesia memiliki ketertarikan terhadap ekonomi syariah (Edi Junaedi, 2009).

Ternyata respon positif ini tidak hanya datang dari masyarakat Indonesia saja. Terbukti bahwa negara Amerika Serikat pun mulai tertarik pada metode bisnis yang berbasis syariah khususnya asuransi syariah, yang ditunjukkan dengan pembelian saham asuransi syariah AmLife dan AmTakaful dari Malaysia oleh perusahaan asuransi Amerika, Metlife. Penandatanganan kerjasama yang berlangsung di Amerika itu disaksikan oleh Presiden Amerika Serikat yaitu Barrack Obama dan Perdana Menteri Malaysia Nazib Razak pada 28 April lalu. Metlife menyetorkan dana sebesar hampir US\$ 250 juta untuk membeli saham AmLife dan AmTalkaful. Peristiwa ini merupakan sejarah bagi Amerika Serikat karena pertama kalinya masuk ke bisnis asuransi syariah Malaysia. Sejak tahun 2003 hingga 2013, AS telah menginvestasikan lebih dari US\$ 13 miliar di Malaysia dan dalam dekade terakhir, ekspor AS ke negara tersebut mencapai US\$ 246,5 miliar, sedangkan impor sebesar US\$ 173,3 miliar (Amerika Serikat Pun Kepincut Asuransi Syariah, 2015).

Semakin tingginya tingkat kepercayaan masyarakat dunia terhadap asuransi syariah, maka pertumbuhan industri asuransi syariah ditargetkan dapat mencapai 35\% per tahunnya (IR, 2014). Seperti dalam laporan Global Takaful Insight 2014, sektor asuransi syariah global diperkirakan akan tumbuh $14 \%$ pada tahun tersebut. Dan untuk pertumbuhan asuransi syariah di kawasan Asia Tenggara, Indonesia termasuk Negara yang mendominasi pasar asuransi syariah dengan pangsa pasar sebesar 23\%, tertinggi kedua setelah Malaysia yang memiliki pangsa pasar sebesar 71\% (EY, 2014).

Grafik 1. Pertumbuhan Kontribusi Bruto Asuransi Syariah Berdasarkan

Wilayah Tahun 2009-2014

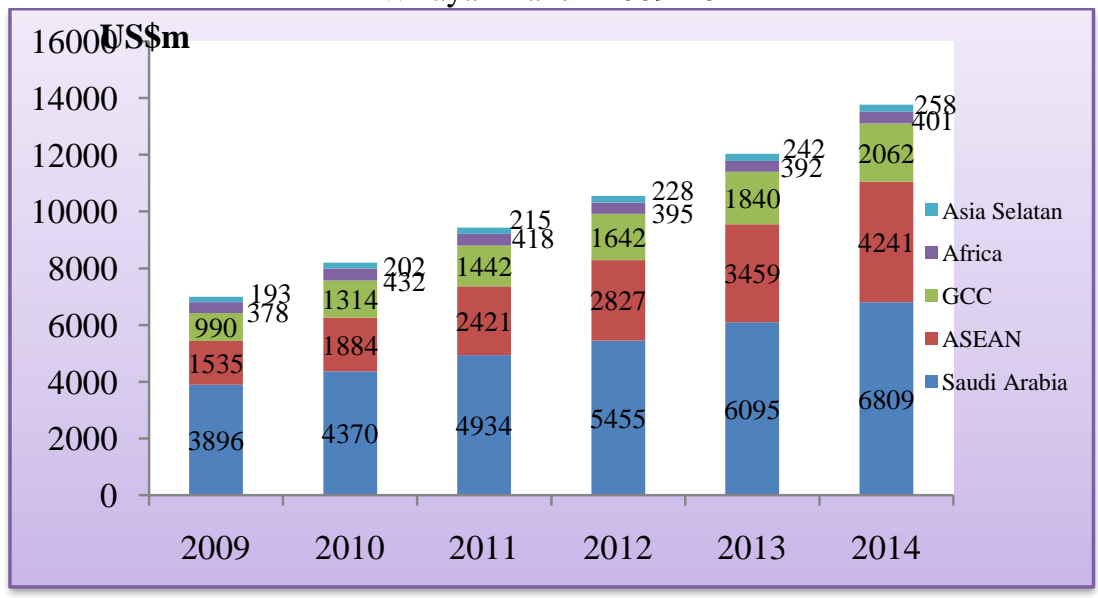

Sumber: Global Takaful Insight 2014 
Pada Grafik 1 terlihat jelas bahwa disetiap tahunnya pertumbuhan kontribusi bruto perusahaan asuransi syariah secara global mengalami pertumbuhan. Untuk pertumbuhan kontribusi bruto dari tahun 2009 hingga 2011 mencapai sekitar 27\% sedangkan dari tahun 2012 hingga 2014 tingkat pertumbuhan kontribusi brutonya sekitar $25 \%$. Indonesia yang berada di wilayah ASEAN bersama dengan Malaysia, Brunei, Singapura dan Thailand berdasarkan laporan Global Takaful Insight 2014 asuransi syariahnya terus mengalami pertumbuhan dikarnakan adanya dukungan dari sistem ekonomi yang kuat dan dinamis. Oleh karena itu dapat dimungkinkan masa depan asuransi syariah di Indonesia akan terus berkembang (EY, 2014). Data dari Otoritas Jasa Keuangan (OJK) menguatkan adanya perkembangan pada sektor asuransi syariah. Yaitu hingga saat ini, aset industri asuransi syariah masih menyumbangkan kenaikan sekitar 29\% terhadap total aset industri keuangan non bank pada kuartal I di tahun 2015 (Kusumawardhani, 2015).

Namun tingkat pertumbuhan premi bruto asuransi syariah Indonesia merupakan pertumbuhan terendah diantara invetasi dan aktiva yang dimiliki oleh perusahaan asuransi syariah. Dapat dilihat pada grafik dibawah ini.

Grafik 2. Pertumbuhan Premi Bruto Asuransi Syariah di Indonesia Periode 2011-2014

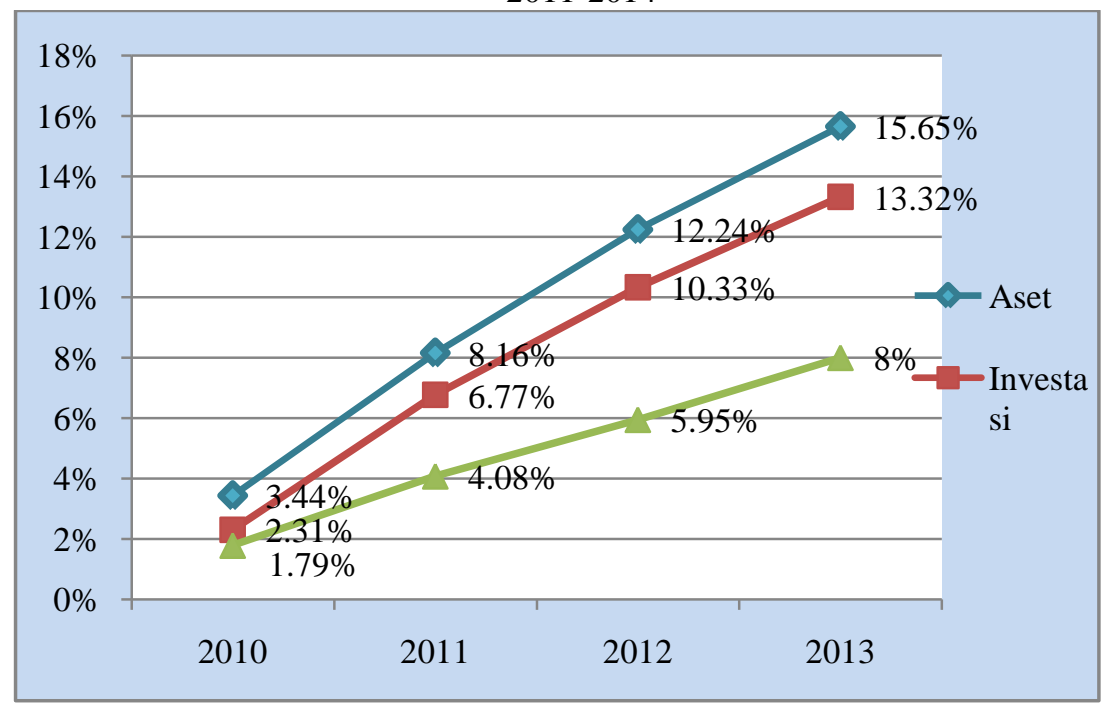

Sumber : Data Statistik Perasuransian diolah, 2014

Dari data statistik perasuransian Otoritas Jasa Keuangan (OJK) diatas, aset, invetasi dan premi bruto perusahaan asuransi syariah mengalami pertumbuhan disetiap tahunnya.Aset asuransi syariah hingga tahun 2013 mengalami pertumbuhan sebesar $15.65 \%$. Investasi perusahaan asuransi syariah ditahun 2013 tumbuh sebesar 13.32\%. Sedangkan pertumbuhan premi bruto hingga tahun 2013 baru mencapai $8 \%$. Pertumbuhan premi bruto ini merupakan yang terendah dibandingkan dengan aset dan investasi.Dari 
sisi premi bruto, market share asuransi syariah tahun 2013 baru sebesar 5.6\% dibanding total premi asuransi nasional (Otoritas Jasa Keuangan, 2014).

Selain ditemukannya data pertumbuhan premi bruto yang melambat pada perusahaan asuransi syariah di Indonesia, tingkat efisiensi pengelolaan dana tabarru pun menjadi sorotan. Menurut Karim Consulting Indonesia dalam Islamic Finance Outlook 2015 menyebutkan bahwa kinerja perusahaan asuransi Syariah dalam mengelola dana tabarru di tahun 2013 masih kurang optimal. Hal ini dapat ditunjukkan dengan hanya 6 asuransi jiwa yang meraih surplus di tahun tersebut, sementara pada asuransi umum masih terdapat 7 perusahaan yang mengalami defisit di tahun tersebut (Islamic Finance Outlook 2015, 2015).

Oleh karena itu, penilaian tingkat efisiensi perusahaan asuransi menjadi suatu hal yang penting untuk dibahas. Karena tingkat efisiensi berguna untuk mengetahui bagaimana kemampuan manajerial perusahaan asuransi syariah tersebut dalam mengelola perusahaannya. Faktor lain dari pentingnya penilaian tingkat efisiensi perusahan asuransi syariah yaitu karna adanya tuntutan persaingan dengan asuransi kovensional. Yang mana asuransi konvensional pada tahun 2013 memiliki pertumbuhan premi bruto sebesar 9,8\% berada di atas pertumbuhan premi bruto asuransi syariah (Otoritas Jasa Keuangan, 2014). Selain itu, para pemegang polis atau para calon nasabah potensial berkepentingan untuk mengetahui kinerja efisiensi perusahaan asuransi syariah. Agar dapat mempercayai perusahaan asuransi tersebut dalam perjanjian dengan jangka waktu yang cukup panjang.

Selama ini metode yang biasa digunakan untuk mengukur tingkat efisiensi adalah dengan menggunakan metode Data Envelopment Analysis (DEA). Efisiensi yang diukur dengan metode DEA memiliki karakter berbeda dengan konsep efisiensi pada umumnya yaitu dapat mengetahui variabel mana yang menjadi sumber inefisiensi. Penelitian ini bertujuan untuk mengukur tingkat efisiensi perusahaan asuransi syariah di Indonesia pada tahun 2010-2014. Sebagai dasar pengukuran efisiensi perusahaanperusahaan asuransi syariah tersebut, studi ini menggunakan analisis DEA (Data Envelopment Analysis), yaitu alat analisis yang didasari teknik programasi linear untuk mengukur efisiensi relatif dari sekumpulan UKE yang dapat diperbandingkan (Nugroho, 1995).

Penelitian mengenai analisis tingkat efisiensi pada perusahaan asuransi syariah dengan menggunakan metode DEA pernah dilakukan di beberapa negara di Asia. Seperti yang dilakukan oleh Abduh, Omar dan Tarmizi (2012) terkait kinerja perusahaan asuransi dengan membandingkan perusahaan asuransi syariah dan perusahaan asuransi konvensional di Malaysia. Dan hasil menunjukkan bahwa asuransi konvensional sedikit lebih efisien dibandingkan dengan asuransi syariah.Ini disebabkan karena produk yang dimiliki asuransi syariah berbeda dengan konvensional dan asuransi syariah masih bergantung kepada asuransi konvensional dari segi operasional dan sistem keuangannya. Selanjutnya Rahman (2013) pernah melakukan penelitian di Bangladesh terkait efisiensi dengan menggunakan pendekatan non-parametic pada perusahaan asuransi jiwa konvensional yang 
dibandingkan dengan perusahaan asuransi jiwa syariah. Hasilnya asuransi syariah atau takaful lebih baik dari segi efisiensi operasionalnya dibandingkan dengan asuransi konvensional.

Khan dan Noreen (2014) membandingkan tingkat efisiensi asuransi konvensional dengan asuransi syariah dengan studi kasus di negara Pakistan. Hasil penelitian menunjukan bahwa asuransi syariah lebih efisien karna perusahaan dapat menggunakan inputnya secara optimal. Miniaoui dan Chaibi (2014) melakukan penelitian mengenai efisiensi teknis perusahaan asuransi syariah dengan membandingkan perusahaan asuransi syariah di negara Malaysia dengan negara-negara GCC. Penelitian ini dilatarbelakangi karna adanya perbedaan hukum yang mendukung antara negara Malaysia dengan negara-negara GCC. Hasilnya menunjukkan bahwa pengaruh hukum tidak ada hubungannya dengan efisiensi, hal ini disebabkan karena tidak adanya variabel hukum yang ditambahkan dalam analisis efisiensi. Penelitian terakhir dilakukan Amri (2015) mengenai efisiensi asuransi syariah di negara-negara GCC untuk periode 2004-2009. Penelitian ini mendapatkan hasil yaitu UEA dan negara Qatar memiliki skor efisiensi teknis tertinggi dibandingkan dengan negara-negara GCC lainnya.

Dari beberapa penelitian internasional mengenai tingkat efisiensi perusahaan asuransi syariah yang sudah disebutkan di atas, mayoritas penelitiannya menggunakan studi komparatif. Yaitu dengan membandingkan efisiensi perusahaan asuransi konvensional dengan perusahaan asuransi syariah ataupun dengan membandingkan efisiensi perusahaan asuransi syariah antar negara. Di Indonesia, penelitian mengenai hal ini masih sangat jarang dilakukan. Penelitian mengenai tingkat efisiensi pada lembaga keuangan syariah lebih banyak dilakukan pada Bank Umum Syariah. Hal inilah yang menarik bagi peneliti untuk melakukan penelitian mengenai tingkat efisiensi pada perusahaan asuransi syariah di Indonesia dengan menggunakan metode Data Envelompent Analysis (DEA). Ini dilakukan karena perusahaan asuransi syariah saat ini sedang mengalami pertumbuhan sebagaimana dengan Bank Syariah. Dan sebagai lembaga bisnis yang menganut prinsip syariah, asuransi syariah juga dituntut untuk memberikan kinerja keuangan yang baik yang dapat dilihat dalam tingkat efisiensi perusahaan tersebut.

\section{LANDASAN TEORI}

\subsection{TEORI EFISIENSI}

Teori efisiensi erat kaitannya dengan teori konsumsi dan teori produksi dalam ekonomi mikro. Efisiensi dalam teori konsumsi yaitu dimana konsumen memiliki kemampuan untuk memaksimalkan utilitas atau kepuasan yang akan dipenuhinya. Sedangkan dalam teori produksi yaitu dimana suatu perusahaan dapat menghasilkan laba yang maksimal atas produksi yang dilakukan. Dalam literatur konvensional, teori produksi akan menggambarkan perlakuan perusahaan dalam membeli dan menggunakan 
masukan (input) untuk produksi dan menjual keluaran (output) berupa produk yang dihasilkan. Dengan begitu pada teori produksi akan terlihat kemampuan perusahaan dalam memaksimalkan keuntungan maupun mengoptimalkan efisiensinya. Efisiensi akan optimal apabila perusahaan dapat memaksimalkan output dengan menggunakan input yang tetap ataupun dengan meminimalkan penggunaan input untuk mencapai tingkat output yang sama (Karim, 2007).

Konsep efisiensi telah dibahas secara umum oleh Farrell (1957) mengenai pengukuran efisiensi dalam perusahaan. Konsep tersebut kemudian dikembangkan oleh Charnes, Cooper dan Rhodes (1978) yang terfokus pada perkembangan pengukuran data perusahaan atau biasa disebut dengan Decision Making Unit (DMU). Di dalam penelitiannya mereka mengembangkan cara bagaimana mengukur efisiensi dari setiap DMU untuk meningkatkan kinerja pada perusahaan yang diukur tersebut. Selanjutnya perkembangan pengukuran konsep efisiensi ini dilanjutkan oleh Banker, Charnes dan Chooper (1984) yang lebih spesifik menekankan pada metode pengukuran inefisiensi teknis dan skala pada metode Data Envelopment Analysis (DEA).Selain mengembangkan konsep pengukuran inefisiensi, dalam penelitiannya mereka juga membuat metode untuk mengukur tingkat efisiensi teknis dan skala dari DMU yang diukur berdasarkan efisiensi Frontier produksi.

Berkaitan dengan efisiensi pada teori produksi, dikenal adanya garis Frontier produksi. Dimana garis ini menggambarkan hubungan antara variabel inputdan outputdalam suatu proses produksi. Garis tersebut sebagaimana ditunjukkan oleh gambar berikut:

Gambar 1. Garis Frontier Produksi

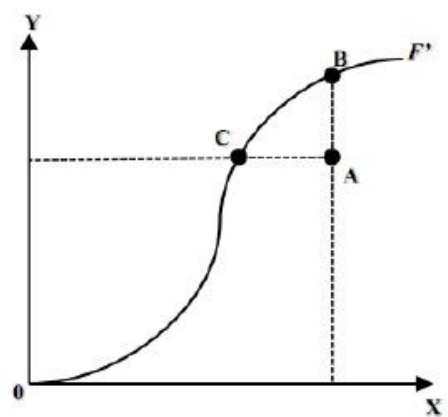

Sumber: (Coelli, Rao, Oe Donnel, \& Battese, 2005)

Garis tersebut menggambarkan bagaimana variabel outputdiperoleh secara maksimum dari setiap tingkatan variabel input. Dimana (x) adalah variabel input dan (y) adalah variabel output. Suatu perusahaan dikatakan efisien secara teknis apabila beroperasi di atas garis Frontier tersebut. Titik yang menunjukkan efisien yaitu titik B dan C. Sedangkan titik A menggambarkan inefisien, karena secara teknis sebenarnya perusahaan dapat meningkatkan outputsampai dengan titik yang bersinggungan dengan titik B 
tanpa harus membutuhkan input yang lebih banyak. Ataupun perusahaan dapat juga memproduksi outputyang tetap namun dengan menggunakan input yang lebih sedikit, seperti yang ditunjukkan oleh titik C. Sehingga produsen dapat memproduksi secara efisien dengan dua pilihan, yaitu mengurangi input atau memaksimalkan input yang ada namun dapat menghasilkan output yang lebih banyak.

Konsep efisiensi dari aspek ekonomis biasa dikenal dengan konsep efisiensi ekonomis atau efisiensi harga.Untuk dapat menentukan optimalitas tingkat produksi dalam aspek ekonomis, menurut konsep efisiensi ekonomis tidak cukup hanya dengan mengetahui fungsi produksi. Ada syarat yang harus diperhatikan yaitu rasio harga-harga input dan output (Wibowo \& Supriadi, 2013).

Menurut Coelli (2005) efisiensi adalah sesuatu yang diukur dengan dua pendekatan, yaitu pendekatan yang berorientasi pada output maupun pendekatan yang berorientasi pada input. Pendekatan yang berorientasi pada output yaitu dimana suatu entitas akan memaksimalkan keuntungannya. Proporsi output yang akan dihasilkan ditingkatkan namun dengan tetap menggunakan tingkatan input yang sama. Sedangkan dalam pendekatan yang berorientasi pada input yaitu dimana entitas akan mengurangkan tingkatan proporsi input untuk menghasilkan outputpada tingkatan yang sama. Dalam pendekatan ini suatu entitas akan meminimalkan biaya dengan mengurangi biaya produksinya.

Jadi secara sederhana, efisiensi merupakan perbandingan antara outputyang dihasilkan dan input yang digunakan. Suatu perusahaan atau organisasi dapat dikatakan efisien apabila perusahaan atau organisasi tersebut dapat menghasilkan output yang lebih besar dengan menggunakan input tertentu, menghasilkan output yang sama dengan input yang lebih rendah dari yang seharusnya, menghasilkan produksi yang lebih besar dari penggunaan sumber dayanya atau yang terakhir dapat mencapai hasil dengan biaya serendah mungkin. Terdapat tiga variabel untuk menilai efisiensi suatu pekerjaan yaitu input, output dan standar efisiensi (Rai, 2008).

\subsection{KONSEP PENGUKURAN EFISIENSI}

Pengukuran efisiensi dapat membantu suatu entitas untuk menilai dan mengevaluasi kinerja serta kemampuan daya saingnya dalam suatu industri. Seberapa besar entitas tersebut dapat mengatasi tantangan dalam industrinya dan mampu bersaing serta bertahan bahkan mengembangkan entitasnya di masa depan. Pengukuran efisiensi dapat dilakukan dengan cara menilai daya saing dari bagian output vs input maupun beban vs return (Shafique, Ahmad, Ahmad, \& Adil, 2015).

Menurut Al Amri (2015) penilaian efisiensi dapat dilihat dari tiga macam efisiensi, yaitu:

1. Technical Efficiency. Efisiensi teknis dapat dilihat dan dinilai dari seberapa efisien teknologi yang digunakan dalam mencapai tingkatan output tertentu atas input yang digunakan. Efisiensi teknis dapat dibagi menjadi dua yaitu efisiensi teknis murni dan efisiensi skala. 
2. Allocative Efficiency. Efisiensi alokasi ini pengukurannya mengacu dari seberapa efisien manajemen dalam memilih inputyang digunakan dengan biaya atau harga yang perlu dikeluarkan. Dengan kata lain, apabila input yang dialokasikan untuk memproduksi output yang tidak dapat digunakan atau diinginkan konsumen, hal ini berarti input tersebut tidak digunakan secara efisien.

3. Cost Efficiency. Efisiensi biaya yaitu kombinasi antara efisiensi teknis dan efisiensi alokatif. Produksi suatu perusahaan dikatakan efisien dalam biayanya jika perusahaan tersebut menggunakan inputataupun biaya yang paling minimal dalam menghasilkan output.

Menurut Farrell (1957) efisiensi suatu perusahaan terdiri dari dua komponen yaitu efisiensi teknis (technical efficiency)dan efisiensi alokatif (allocative efficiency). Efisiensi teknis yaitu mengukur kemampuan suatu perusahaan untuk mencapai tingkat output yang maksimal dari beberapa komponen inputyang digunakan. Sedangkan efisiensi alokatif yaitu mengukur kemampuan perusahaan dalam menggunakan input pada proporsi yang optimal. Dari kedua pengukuran tersebut kemudian digabungkan untuk mengukur efisiensi ekonomi secara menyeluruh atau dikenal dengan overall efficiency. Suatu perusahaan dapat dikatakan efisien secara ekonomi apabila dapat meminimalkan biaya produksinya dalam menghasilkan output pada tingkatan tertentu dengan suatu tingkat teknologi yang umumnya digunakan serta harga pasar yang berlaku.

Kemudian efisiensi teknis dapat dibagi menjadi dua yaitu efisiensi teknis murni (pure technical efficiency) dan efisiensi skala (scale efficiency) (Banker, Charnes, \& Cooper, 1984). Perbedaan dari efisiensi teknis murni dan skala dapat dilihat pada gambar di bawah ini:

Gambar 2. Garis Efisiensi Teknis dan Skala

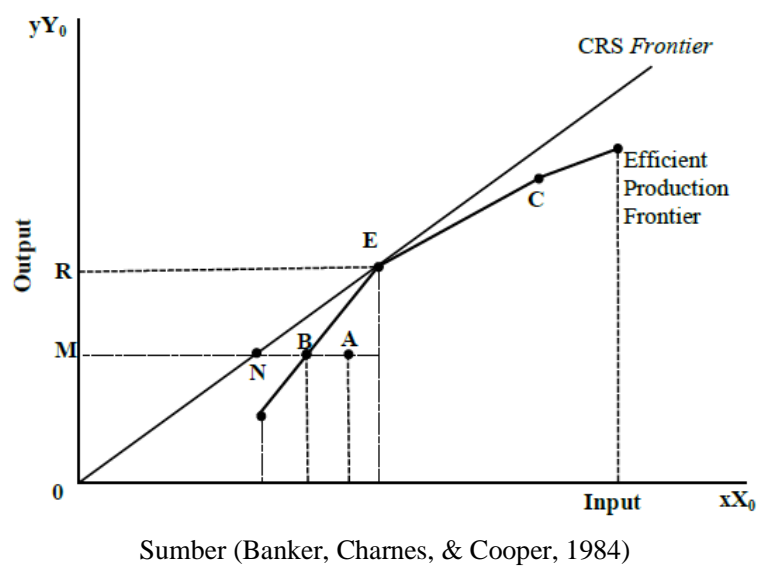

Dari gambar di atas, titik A adalah mewakili Decision Making Unit (DMU) yang diukur. Efisiensi teknis murni dari titik A dengan rasio $M B / M A$ dan membandingkan dengan titik B pada Frontier efisiensi produksi dengan 
ukuran skala yang sama dengan A. Dan efisiensi skala dari titik A diukur dengan rasio $M N / M B$, karenanya seluruh efisiensi teknis dan skala $M N / M B$ setara hasilnya dengan hasil dari efisiensi teknis $M B / M A$ dan efisiensi skala $M N / M B$. Pengukuran efisiensi teknis dan skala agregat $M N / M A$ ini lebih sedikit daripada pengukuran efisiensi teknis murni $M B / M A$. (Banker, Charnes, \& Cooper, 1984)

Menurut Muharam dan Pusvitasari (2007) ada tiga jenis pendekatan pengukuran efisiensi, yaitu:

1. Pendekatan rasio

Pendekatan rasio yaitu dengan membandingkan output yang dihasilkan dengan input yang digunakan. Dalam pendekatan ini, efisiensi yang tinggi apabila dapat memproduksi jumlah output yang maksimal dengan input yang seminimal mungkin.

$$
\text { Efisiensi }=\frac{\text { Output }(\mathrm{y})}{\operatorname{Input}(x)}
$$

2. Pendekatan regresi

Pendekatan regresi yaitu dalam mengukur efisiensi dalam pendekatan ini menggunakan sebuah metode dari tingkat output tertentu sebagai fungsi dari berbagai tingkat input tertentu. Persamaan regresi dapat ditulis dengan fungsi sebagai berikut:

$$
\mathrm{Y}=\mathrm{f}\left(X_{1}, X_{2}, X_{3}, X_{4}, \ldots \ldots X_{n}\right)
$$

\section{Dimana $\mathrm{Y}=$ Output $\operatorname{dan} \mathrm{X}=$ Input}

Dalam pendekatan ini, akan dinilai efisiensi apabila dapat menghasilkan ouput lebih banyak dibandingkan estimasinya. Namun dalam pendekatan ini tidak dapat mengukur efisiensi dengan jumlah output yang banyak, karna hanya satu outputyang dapat menjadi indikator.

\section{Pendekatan Frontier}

Pendekatan Frontier dalam mengukur tingkat efisiensi dibedakan menjadi dua jenis, yaitu pendekatan Frontier parametric dan nonparametric. Pendekatan parametik diukur dengan tes statistik parametik seperti menggunakan Stochastic Frontier Approach (SFA) dan Distribusi Free Approach (DFA). Sedangkan pendekatan Frontier non parametic diukur dengan tes statistik non parametik yaitu dengan menggunakan metode Data Envelopment Analysis (DEA).

Dalam penelitian ini pendekatan yang akan digunakan adalah pendekatan Frontiernon parametic yaitu dengan menggunakan Data Envelopment Analysis (DEA). Karena pendekatan Frontier ini sudah banyak digunakan untuk menganalisis serta mengukur efisiensi kinerja dalam Lembaga Keuangan. (Ascarya \& Yumanita, 2008)

Selain tiga pendekatan di atas, terdapat 3 pendekatan lain yang biasa digunakan dalam metode parametrik dan metode non-parametrik dalam 
mengukur hubungan antara input dan output dalam kegiatan suatu lembaga keuangan (Muharam \& Pusvitasari, 2007). Tiga pendekatan tersebut yaitu:

1. Pendekatan Aset (The Assets Approach)

Pendekatan aset menggambarkan fungsi utama suatu lembaga keuangan sebagai pemberi pinjaman. Pada pendekatan ini, output yang diukur benar-benar didefinisikan kedalam bentuk aset.

2. Pendekatan Produksi (The Production Approach)

Pendekatan produksi menggambarkan suatu lembaga keuangan disini sebagai produsen dari akun depositonya dan kredit pinjamannya, lalu mendefinisikan output sebagai jumlah tenaga kerja, pengeluaran modal pada aset tetap dan material lainnya.

3. Pendekatan Intermediasi (The Intermediation Approach)

Pendekatan intermediasi menggambarkan suatu lembaga keuangan sebagai intermediator atau perantara antara unit surplus dengan unit defisit. Dalam kondisi ini biasanya input yang digunakan yaitu biaya tenaga kerja, modal dan pembayaran bunga pada deposan. Dan output yang digunakan biasanya kredit pinjaman ataupun pendapatan investasi.

Dengan adanya 3 pendekatan ini, maka dalam mengukur efisiensi lembaga keuangan keputusan untuk menentukan variabel input dan variable output yang akan digunakan pun akan berbeda.

\subsection{KONSEP EFISIENSI DALAM PANDANGAN ISLAM}

Selama dalam melakukan penelitian, peneliti belum menemukan rujukan yang khusus membahas tentang efisiensi dalam pandangan Islam. Namun penulis akan berusaha menganalisis dari Al-Quran, Hadits serta pandangan para ulama ekonomi islam yang berkaitan dengan efisiensi. Seperti yang sudah dijelaskan di atas pada point teori efisiensi bahwasannya efisiensi berkaitan dengan teori konsumsi dan teori produksi. Yang mana dalam teori konsumsi Islam menurut Imam Al Ghazali bahwa sesorang yang ingin memenuhi kebutuhannya dengan semaksimal mungkin atau "selalu ingin lebih" harus berhati-hati karna dikhawatirkan akan mencapai pada tingkat keserakahan dan pengejaran nafsu pribadi. Selain itu Imam Al Ghazali memandang bahwa perkembangan ekonomi merupakan bagian dari kewajiban sosial (fardhu kifayah) yang sudah ditetapkan oleh Allah SWT. Jika kewajiban ini tidak dipenuhi maka dunia akan binasa. Jadi Imam Al Ghazali berpendapat bahwa kegiatan yang berkaitan dengan kewajiban sosial untuk mengembangkan ekonomi harus dilakukan secara efisien (Karim, 2007).

Sedangkan konsep efisiensi yang berkaitan dengan teori produksi islam yaitu dimana produksi lahir dan tumbuh karna manusia yang menyatu dengan alam. Maka untuk menyatukan manusia dengan alam Allah SWT menunjuk manusia sebagai khalifah di muka bumi.Tugas manusia sebagai khalifah yaitu mengelola sumber daya yang disediakan oleh Allah SWT 
secara efisien dan optimal agar kesejahteraan dan keadilan dapat tercipta dengan baik.Segala bentuk kegiatan ekonomi yang ditujukan untuk mencari keuntungan tanpa berakibat pada nilai guna sumber daya yang ada tidak disukai dalam Islam (Karim, 2007).

Tujuan dari efisiensi sendiri berdasarkan konsep konvensional adalah untuk mendapatkan profit yang maksimal dengan biaya yang minimal. Pelaku bisnis akan selalu berusaha untuk mendapatkan keuntungan yang banyak dan meminimalisir biaya yang dikeluarkan dengan tujuan untuk mensejahterakan dirinya dan atau mengembangkan bisnisnya. Hal ini memang sejalan dengan tujuan dari mencari rezeki agar Allah SWT mencukupkan keperluan hambaNya di muka bumi. Ada beberapa dalil yang menjadi landasan umat islam dalam mencari rezeki agar hidupnya menjadi layak dan mampu melaksanakan semua rukun islam. Karna harta itu didapat bukan karna datang dengan sendirinya, melainkan didapat melalui usaha dan kerja keras. Sebagaimana tertuang dalam firman Allah SWT

Artinya: "Apakah mereka yang membagi-bagikan rahmat Tuhanmu? Kamilah yang menentukan penghidupan mereka di dunia, dan kami telah meninggikan sebagian mereka atas sebagian lainnya.Dan Rahmat Tuhanmu lebih baik dari apa yang mereka kumpulkan.”(Q.S. Az-Zukhruf: 32)

Dalam penjelasan tafsir Ibnu Katsir, Allah SWT menjelaskan bahwa Dia telah membeda-bedakan hambaNya berdasarkan atas apa yang telah diberikan dalam hal harta kekayaan, rezeki, akal, pemahaman dan sebagainya yang merupakan kekuatan lahir dan batin. Oleh karena itu, satu sama lain harus saling bekerja keras untuk mempergunakan potensinya dalam beramal dan mencari karunia Allah SWT.

Selain bekerja keras untuk mencari rezeki, cara untuk mendapatkan efisiensi yaitu manusia juga harus memanfaatkan potensi yang telah Allah SWT karuniakan kepadanya. Allah telah memudahkan dan menganjurkan manusia agar senantiasa memanfaatkan seluruh potensi yang ada di muka bumi demi terpenuhinya segala kebutuhan hidupnya. Ini sesuai dengan firman Allah:

Artinya: "Dia-lah yang telah menjadikan bumi mudah untuk dijelajahi untuk kamu. Maka jelajahilah di segala penjurunya, dan makanlah sebagian dari rezeki-Nya. Dan hanya kepada-Nya kamu (kembali setelah) dibangkitkan" (Q.S. Al-Mulk : 15)

Ayat ini menjelaskan bahwa Allah SWT memerintahkan manusia untuk berjelajah ke segala penjuru bumi yang diinginkan untuk membawa berbagai macam hasil usaha karena Allah SWT telah memberikan kemudahan, serta agar berusaha dalam memperoleh sarana yang tidak bertentangan dengan kewajiban bertawakal kepada Allah SWT. Karna pada hakekatnya hanya kepada Allah SWT semua akan kembali. Namun Islam melarang manusia untuk mencari harta dengan cara yang bathil termasuk larangan menimbun barang untuk mendapatkan keuntungan yang lebih banyak. Larangan ini sesuai dengan firman Allah SWT. 
Artinya: "Hai orang-orang yang beriman, janganlah kamu memakan riba dengan berlipat ganda dan bertakwalah kepada Allah agar kalian mendapatkan keberuntungan" (Q.S. Ali-Imran : 130)

Pada ayat ini Allah SWT melarang hamba-hambaNya untuk mendapatkan harta dengan cara yang bathil. Salah satunya dengan memakan riba secara berlipat ganda seperti yang dahulu biasa dilakukan dalam transaksi hutang piutang.

Larangan lainnya dalam Islam untuk mencari rezeki yaitu adanya larangan untuk berlebih-lebihan. Produsen hendaknya memperhitungkan secara cermat anggaran yang akan dikeluarkannya dalam memproduksi suatu barang agar tidak terjadi pengeluaran yang berlebih-lebihan sehingga memperbesar biaya pengeluaran. Selain itu, harus memperhatikan produknya agar mencukupi kebutuhan masyarakat dan tidak menjadikan konsumen bermewah-mewahan dengan produk tersebut. Larangan untuk berlebihlebihan ini terdapat dalam firman Allah SWT

Artinya: "Dan Dialah yang menjadikan kebun-kebun berjunjung dan yang tidak berjunjung, pohon kurma, tanaman-tanaman yang bermacammacam buahnya, zaitun dan delima yang serupa (bentuk dan warnanya) dan tidak sama (rasanya). Makanlah dari buahnya (yanng bermacam-macam itu) bila dia berbuah, dan tunaikanlah hanya dihari memetik hasilnya tapi janganlah kamu berlebih-lebihan.Sesungguhnya Allah tidak menyukai orang yang berlebih-lebihan. "(Q.S. Al-An'am : 141)

Ayat ini jika ditinjau dari makna lahiriyahnya, maka maksud dari ayat ini adalah larangan berlebihan dam makan karena dapat memberikan mudharat pada akal dan tubuh.

Dari pembahasan di atas, dapat disimpulkan bahwa Islam membatasi pelaku ekonomi dalam menjalankan usahanya tidak menjadi penghambat untuk memperoleh keuntungan. Tidak ada definisi murni tentang efisiensi, baik itu dari segi keuntungan atau outputmaupun dari segi biaya atau nput. Islam mengharuskan kaffah dalam menjalankan setiap aktivitas, namun dengan tidak melanggar batasan-batasan yang telah Allah SWT tentukan agar hasilnya selalu optimal dan tidak ada yang dirugikan atau terzhalimi.

\subsection{PENELITIAN TERDAHULU}

Penelitian mengenai tingkat efisiensi pada perusahaan asuransi syariah sudah dilakukan oleh beberapa peneliti terdahulu. Penelitian mengenai tingkat efisiensi perusahaan asuransi syariah dilakukan di beberapa negara di ASIA. Namun para peneliti lebih sering menggunakan perbandingan untuk mengukur efisiensi perusahaan asuransi syariah dengan asuransi konvensional ataupun membandingkan perusahaan asuransi syariah antar negara. Berikut adalah uraian mengenai beberapa penelitian sebelumnya yang membahas mengenai tingkat efisiensi perusahaan asuransi syariah.

Abduh (2012) meneliti tentang kinerja industi asuransi syariah di Malaysia dengan membandingkan antara perusahaan asuransi syariah dengan perusahaan asuransi konvensional. Sampel yang digunakan yaitu 7 perusahaan asuransi konvensional dan 5 perusahaan asuransi syariah dalam 
periode 2008-2010. Metode penelitian yang digunakan dalam penelitian ini yaitu analisis rasio dan Data Envelopment Analysis (DEA). Variabel input yang digunakan yaitu biaya komisi dan biaya manajemen, sedangkan variabel outputnya yaitu penerimaan premi dan pendapatan investasi. Hasil dari penelitian menunjukkan bahwa asuransi konvensional lebih sedikit efisien dibandingkan dengan asuransi syariah. Penyebab hal ini dikarenakan asuransi syariah memiliki produk yang berbeda namun dioperasikan di bawah sistem keuangan yang sama dengan asuransi konvensional.

Penelitian selanjutnya dilakukan oleh Rahman (2013) yang membahas tentang perbandingan efisiensi asuransi jiwa konvensional dengan asuransi jiwa syariah di Bangladesh dengan pendekatan non-parametic. Sampel yang digunakan dalam penelitian ini yaitu 13 perusahaan asuransi konvensional dan 3 perusahaan asuransi syariah pada periode 2009-2011. Variabel input dan variabel output yang digunakan dalam penelitian ini sama dengan variabel yang digunakan oleh Abduh (2012). Variabel inputnya yaitu biaya komisi dan biaya manajemen, sedangkan variabel outputnya yaitu premi dan pendapatan bersih investasi. Namun hasil dari penelitian ini berbeda dengan hasil penelitian yang dilakukan Abduh (2012). Hasilnya menunjukkan bahwa asuransi jiwa syariah lebih baik dibandingkan dengan asuransi jiwa konvensional dari segi efisiensi operasionalnya.

Penelitian mengenai tingkat efisiensi dilakukan oleh Khan (2014) di negara Pakistan. Penelitian ini dilakukan dengan membandingkan perusahaan asuransi konvensional dan asuransi syariah dengan menggunakan pendekatan Data Envelopment Analysisi (DEA). Tujuan dari penelitian ini untuk membandingkan asuransi syariah dan konvensional dari segi efisiensi dan produktivitasnya. Sampel yang digunakan dalam penelitian ini yaitu 12 asuransi konvensional dan 5 asuransi syariah pada periode 2006-2010. Variabel input yang digunakan yaitu biaya gaji, total aset tetap, biaya manajemen dan modal. Sedangkan variabel output nya yaitu investasi dan premi bersih. Meskipun variabel input dan output yang digunakan berbeda dengan 2 penelitian sebelumnya, namun hasil dari penelitian ini sama dengan hasil dari penelitian Rahman (2013). Hasilnya yaitu asuransi syariah lebih efisien daripada asuransi konvensional karena variabel inputnya digunakan dengan optimal. Dan dari penelitian ini sektor alokasi biaya pada asuransi konvensional tidak efisien.

Miniaoui (2014) melakukan penelitian mengenai efisiensi teknik industri asuransi syariah di Malaysia dengan menggunakan studi komparatif antara Malaysia dan negara-negara GCC (Gulf Corporation Council). Alasan memilih membandingkan antara Malaysia dengan negara-negara GCC dikarenakan asuransi syariah di Malaysia sedang mengalami pertumbuhan secara pesat dengan adanya dukungan dari pemerintah. Sedangkan negaranegara GCC tidak adanya dukungan hukum dari pemerintah namun tingkat efisiensi operasionalnya lebih tinggi dibandingkan dengan Malaysia ditahun 2010. Sampel yang digunakan yaitu 12 perusahaan periode 2006-2009. 3 perusahaan asuransi syariah di UEA, 2 di Saudi Arabia, 2 di Qatar, 1 di Bahrain dan 4 di Malaysia. Variabel input yang digunakan yaitu biaya 
administrasi dan umum serta total aset. Sedangkan variabel outputnya yaitu kontribusi bruto. Hasil dari penelitian ini menunjukkan bahwa pengaruh hukum tidak ada hubungannya dengan efisiensi. Karena tidak ada variabel hukum yang ditambahkan dalam analisis efisiensi.

Penelitian ini ditutup oleh penelitian yang dilakukan oleh $\mathrm{Al}$ Amri (2015). Peneliti melakukan penelitian tentang efisiensi asuransi syariah di negara-negara GCC pada periode 2004-2009. Variabel input yang digunakan yaitu biaya gaji, modal dan hutang. Sedangkan variabel outputnya yaitu kontribusi bruto dan investasi. Efisiensi yang diukur dalam penelitian ini yaitu tingkat efisiensi biayanya dengan menggunakan pendekatan efisiensi teknis dan efisiensi alokasi. Hasil dari penelitian ini yaitu efisiensi teknis dan efisiensi rata-rata biaya dan alokasinya sudah cukup efisien. Negara dengan skor efisiensi teknis yang tertinggi yaitu negara UEA dan Qatar. Sedangkan negara dengan skor efisiensi biaya paling tinggi diperoleh negara Saudi Arabia dan UEA.

\section{METODOLOGI PENELITIAN}

Penelitian ini akan mendeskripsikan atau menggambarkan hasil dari analisis yang dilakukan dalam mengukur efisiensi pada Perusahaan Asuransi Syariah di Indonesia.

Variabel dalam penelitian ini adalah tingkat efisiensi perusahaan asuransi syariah. Karena dalam penelitian ini akan dilakukan analisis efisiensi pada perusahaan asuransi syariah, maka diperlukan variabel inputdan variabel output untuk menjadi alat ukur tingkat efisiensinya. Variabel input dan variabel output yang digunakan dalam penelitian ini adalah sebagai berikut:

Tabel 1. Variabel Input dan Variabel Output Penelitian

\begin{tabular}{|c|c|c|c|}
\hline $\begin{array}{l}\text { Variabel } \\
\text { Input }\end{array}$ & Definisi & Sumber Data & Referensi \\
\hline Total Aset & $\begin{array}{l}\text { Keseluruhan dari aset lancar } \\
\text { dan aset non lancer }\end{array}$ & $\begin{array}{l}\text { Laporan Posisi } \\
\text { Keuangan } \\
\text { (Neraca) }\end{array}$ & $\begin{array}{l}\text { (Miniaoui \& } \\
\text { Chaibi, 2014) }\end{array}$ \\
\hline $\begin{array}{l}\text { Biaya } \\
\text { Komisi }\end{array}$ & $\begin{array}{l}\text { Biaya yang harus } \\
\text { dikeluarkan oleh perusahaan } \\
\text { asuransi yang diberikan } \\
\text { kepada agen atau broker } \\
\text { karena adanya jasa yang } \\
\text { diterima. }\end{array}$ & $\begin{array}{ll}\text { Laporan } & \text { Laba } \\
\text { Rugi Dana } \\
\text { Perusahaan }\end{array}$ & $\begin{array}{l}\text { (Rahman, } \\
\text { 2013) }\end{array}$ \\
\hline $\begin{array}{c}\text { Variabel } \\
\text { Output }\end{array}$ & Definisi & Sumber Data & Referensi \\
\hline $\begin{array}{l}\text { Kontribusi } \\
\text { Bruto }\end{array}$ & $\begin{array}{l}\text { Jumlah bruto yang menjadi } \\
\text { kewajiban peserta untuk } \\
\text { porsi risiko dan ujrah. }\end{array}$ & $\begin{array}{l}\text { Laporan } \\
\text { Surplus } \\
\text { (Defisit) } \\
\text { Underwriting }\end{array}$ & $\begin{array}{l}\text { (Al-Amri, } \\
\text { 2015) }\end{array}$ \\
\hline
\end{tabular}




\begin{tabular}{llllll}
\hline & & & Dana Tabarru' & \\
\hline & Hasil dari kegiatan suatu & Laporan & (Abduh, \\
Pendapatan & entitas dalam melakukan & Surplus & Omar, \& \\
Investasi & $\begin{array}{l}\text { investasi atas harta yang } \\
\text { dimilikinya. }\end{array}$ & Underwriting & $\begin{array}{l}\text { Tarmizi, } \\
\text { Dana Tabarru' }\end{array}$ & \\
& & & \\
\hline
\end{tabular}

Sampel dalam penelitian ini hanya Perusahaan Asuransi Syariah yang mempublikasikan laporan keuangan secara lengkap pada periode 2012-2014. Sampel dalam penelitian ini disajikan dalam tabel berikut:

Tabel 2. Sampel Penelitian

\begin{tabular}{|c|c|c|c|}
\hline NO & Keterangan & Populasi & $\begin{array}{c}\text { Data Sampel } \\
\text { Lap.Keuangan } \\
\text { 2012-2014 }\end{array}$ \\
\hline
\end{tabular}

\begin{tabular}{llcc}
\hline 1. & Asuransi Umum Syariah & 3 & 6 \\
\hline 2. & Asuransi Jiwa Syariah & 3 & 3 \\
\hline 3. & Unit Syariah Asuransi Umum & 23 & 21 \\
\hline 4. Unit Syariah Asuransi Jiwa & 18 & 36 \\
\hline Total Sampel & 22 & 66 \\
\hline Penelitian ini menggunakan metode & Data & Envelopment Analysis \\
(DEA) dengan menggunakan software Banxia Frontier Analysist 3. \\
Kelebihan metode ini adalah adanya kemungkinan untuk mengukur efisiensi \\
relatif terhadap nilai terbaik dari produsen yang terbaik di dalam sampel \\
(Akbar, 2009).
\end{tabular}

\section{PEMBAHASAN}

Perusahaan Asuransi Syariah merupakan salah satu Lembaga Keuangan Syariah di Indonesia.Bagian terpenting dari industri asuransi ini adalah kemampuannya dalam menawarkan keamanan finansial bagi tertanggung, yang meliputi seluruh aspek kehidupan dan bisnis (Mansor \& Radam, 2000). Dari pengolahan data laporan keuangan 22 perusahaan Asuransi Syariah di Indonesia yang dijadikan sampel penelitian, penulis melakukan pengukuran efisiensi secara keseluruhan untuk membandingkan tingkat efisiensi antar Perusahaan Asuransi Syariah. Tingkat efisiensi Perusahaan Asuransi Syariah dalam penelitian kali ini diukur dalam 3 pengukuran yaitu efisiensi teknis, efisiensi teknis murni dan efisiensi skala.

Pendekatan yang digunakan dalam penelitian ini yaitu pendekatan intermediasi dan dengan orientasi input. Pemilihan orientasi input (minimize input) ini dikarenakan perusahaan asuransi lebih baik mengoptimalkan perusahaannya agar dapat bekerja secara optimal pada pangsa pasarnya sendiri. Karena ketika suatu perusahaan sudah beroperasi secara optimal maka akan lebih mudah untuk bersaing dengan perusahaan lainnya.

Hasil dari pengolahan dengan menggunakan metode DEA pada perusahaan Asuransi Syariah periode 2012-2014 akan dianalisis berdasarkan 
kelompok Perusahaan Asuransi Syariah. Dalam penelitian ini Perusahaan Asuransi Syariah dibagi menjadi 4 kelompok, yaitu kelompok Asuransi Umum Syariah, kelompok Unit Syariah Asuransi Umum, kelompok Asuransi Jiwa Sayriah dan kelompok Unit Syariah Asuransi Jiwa.

\subsection{TREN TINGKAT EFISIENSI TEKNIS, EFISIENSI TEKNIS MURNI DAN EFISIENSI SKALA PADA SETIAP PERUSAHAAN ASURANSI SYARIAH}

Seperti yang sudah dijelaskan di atas, hasil dari pengukuran tingkat efisiensi setiap Perusahaan Asuransi Syariah akan dianalisis berdasarkan kelompok yang telah dibuat. Karna setiap kelompok Perusahaan Asuransi Syariah memiliki karakteristik operasional yang berbeda-beda sehingga analisis lebih tepat dilakukan apabila setiap perusahaan dilihat berdasarkan kelompoknya masing-masing. Setiap Perusahaan Asuransi Syariah akan diukur dengan 3 pengukuran, yaitu efisiensi teknis, efisiensi teknis murni dan efisiensi skala. Efisiensi teknis untuk mengukur kemampuan dari sebuah perusahaan untuk mencapai tingkatan output yang maksimal dari komponen input yang digunakan. Efisiensi teknis murni untuk mengukur kemampuan perusahaan dalam menghindari pemborosan dengan memproduksi sebanyak mungkin output dengan menggunakan input yang sedikit. Dan efisiensi skala merupakan sebuah pengukuran yang mengacu pada eksploitasi skala ekonomis dengan beroperasi pada suatu titik dimana Frontier produksi berada pada kondisi constant Return to Scale .(Hassine \& Limani, 2014)

Pada kelompok Perusahaan Asuransi Umum Syariah, terdapat 2 Perusahaan yang dapat mewakili kelompok ini yaitu PT Asuransi Takaful Umum dan PT Jaya Proteksi Takaful.

Pada kelompok Unit Syariah Perusahaan Asuransi Umum, terdapat 7 Perusahaan yang menjadi sampel penelitian sekaligus mewakili kelompok Unit Syariah Perusahaan Asuransi Umum ini. Ke 7 perusahaan tersebut yaitu PT Allianz Utama Indonesia, PT Asuransi Astra Buana, PT Asuransi Bangun Askrida, PT Asuransi Bintang, PT Asuransi Ramayana Tbk, PT Asuransi Sinar Mas dan PT Tugu Pratama Indonesia.

Selain melihat tingkat efisiensi masing-masing perusahaan asuransi syariah dan mengetahui perusahaan mana saja yang dijadikan referensi, metode DEA juga dapat mengukur dan memastikan bahwa DMU (Decision Making Unit) sudah melakukan peningkatan kapasitas produksinya atau belum. Dalam hal ini setiap DMU akan berada pada salah satu dari tiga kondisi Return to Scale (RTS) yaitu Increasing Return to Scale (IRS), Constant Return to Scale (CRS) dan Decreasing Return to Scale (DRS

Kondisi CRS, DRS, dan IRS pada Perusahaan Asuransi Syariah di Indonesia pada penelitian ini dapat dilihat pada grafik di bawah ini:

Grafik 3. Return to Scale Perusahaan Asuransi Syariah di Indonesia 


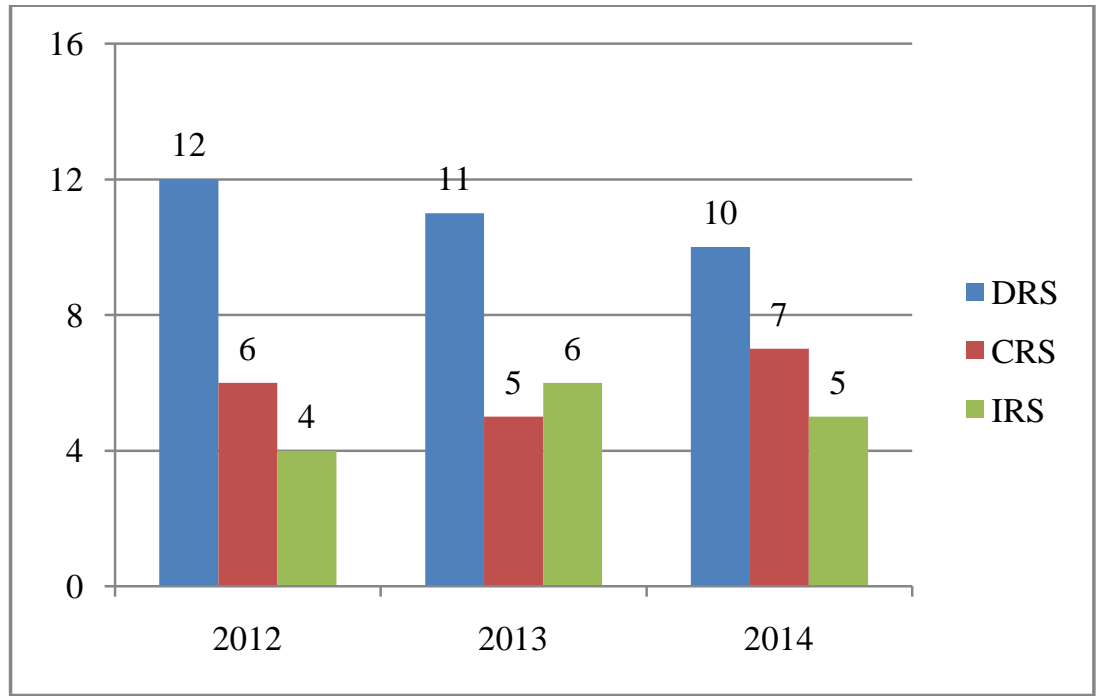

Sumber: Software Banxia Frontier Analyst 3, data diolah

Dari grafik tersebut dapat dilihat secara umum tiga kondisi Return to Scale(RTS) Perusahaan Asuransi Syariah di Indonesia. Pada kondisi CRS atau kondisi dimana perusahaan dikatakan efisien secara relatif terbanyak terjadi pada tahun 2014 yaitu sebanyak 7 perusahaan atau sebesar 32\%. Dan pada kondisi DRS trennya cenderung menurun dari tahun 2012-2014. Ini menunjukkan bahwa semakin banyak Perusahaan Asuransi Syariah yang sudah mulai memperbaiki inputnya. Dan kondisi terakhir yaitu IRS menunjukkan tren yang lebih fluktuatif dimana pada tahun 2013 merupakan tahun dengan jumlah perusahaan asuransi syariah yang paling banyak diperlukan peningkatan produksi outputnya dibandingkan dengan tahuntahun lainnya. Dari sinilah dapat dilihat bahwa rata-rata Perusahaan Asuransi Syariah perlu memperbaiki input serta meningkatkan output-nya, sehingga dapat tercapai tingkat efisiensi.

Selain mengukur tingkat efisiensi dan Return to Scale (RTS) pada bagian sebelumnya, dengan metode DEA yang digunakan ini dapat mengetahui potensi perbaikan (Potential Improvement) dari masing-masing DMU (Decision Making Unit) yang tidak efisien. Besarnya potensi perbaikan Perusahaan Asuransi Syariah yang tidak efisien (inefisien) akan mengacu kepada Perusahaan Asuransi Syariah yang efisien (benchmarking). Perusahaan Asuransi Syariah yang tidak efisien menunjukkan bahwa Perusahaan Asuransi tersebut belum mengoptimalkan input dan output sesuai dengan target yang seharusnya dicapai. Sumber inefisien Perusahaan Asuransi Syariah di Indonesia dapat dilihat pada tabel berikut:

Tabel 3. Potential Improvement Perusahaan Asuransi Syariah di Indonesia Minimize Input

\begin{tabular}{lccc}
\hline & 2012 & 2013 & 2014 \\
\hline Total Aset & -42.73 & -46.65 & -39.66 \\
\hline
\end{tabular}




\begin{tabular}{lccc} 
Biaya Komisi & -42.71 & -46.65 & -39.66 \\
\hline Kontribusi Bruto & 0 & 0 & 1.44 \\
\hline Pendapatan Investasi & 32.98 & 9.12 & 11.95 \\
\hline Maximize Output & & & \\
\hline & 2012 & 2013 & 2014 \\
\hline Total Aset & -0.09 & 0 & 0 \\
\hline Biaya Komisi & 0 & 0 & 0 \\
\hline Kontribusi Bruto & 195.40 & 198.65 & 165.50 \\
\hline Pendapatan Investasi & 271.28 & 222.19 & 199.69 \\
\hline
\end{tabular}

Sumber: Software Banxia Frontier Analyst 3, data diolah

Selama periode pengamatan dari tahun 2012 sampai 2014, variabel yang menyebabkan inefisiensi dengan nilai perbaikan paling besar yaitu Pendapatan Investasi. Nilai perbaikan Pendapatan Investasi lebih besar daripada nilai perbaikan Kontribusi Bruto. Pendapatan Investasi dalam Perusahaan Asuransi Syariah juga merupakan sesuatu yang penting karna dapat memberikan tambahan pada Surplus (Defisit) Underwriting Dana Tabarru'. Dengan adanya perbaikan pada variabel ini diharapkan dapat tercapai tingkat efisiensi intermediasi pada Perusahaan Asuransi Syariah. Namun selain perbaikan pada variabel Pendapatan Investasi, selama periode pengamatan variabel yang lainnya juga perlu adanya perbaikan baik dari pendekatan minimize input maupun maximize output.

Setelah melihat tingkat efisiensi Perusahaan Asuransi Syariah dari tiga jenis pengukuran dan juga telah mengetahui sumber dari inefisiennya, pada bagian ini penuli akan memberikan peringkat kepada setiap DMU (Decision Making Unit) Perusahaan Asuransi Syariah. Peringkat diberikan berdasarkan rata-rata skor efisiensi yang didapatkan setiap DMU (Decision Making Unit). Peringkat efisiensi Perusahaan Asuransi pada kelompok Perusahaan Asuransi Umum Syariah Indonesia dapat dilihat pada tabel berikut:

Tabel 4. Peringkat Perusahaan Asuransi Umum Syariah di Indonesia

\begin{tabular}{lc}
\hline \multicolumn{1}{c}{ Nama Perusahaan } & Peringkat \\
\hline 2014 Takaful Umum & 1 \\
\hline 2012 Takaful Umum & 2 \\
\hline 2013 Jaya Proteksi & 3 \\
\hline 2013 Takaful Umum & 4 \\
\hline 2012 Jaya Proteksi & 5 \\
\hline 2014 Jaya Proteksi & 6 \\
\hline
\end{tabular}

Perusahaan Asuransi Umum Syariah yang memiliki rata-rata skor efisiensi tertinggi dari ketiga pengukuran (teknis, teknis murni dan skala) pada periode pengamatan tahun 2012-2014 yaitu PT Asuransi Takaful Umum.

Setelah melihat peringkat dari Perusahaan-perusahaan Asuransi Umum Syariah, selanjutnya peringkat Unit Syariah dari Perusahaan Asuransi umum dapat dilihat pada tabel berikut: 
Tabel 5. Peringkat Unit Syariah Perusahaan Asuransi Umum Syariah di Indonesia

\begin{tabular}{|c|c|}
\hline Nama Perusahaan & Peringkat \\
\hline 2013 Asuransi Bintang & 1 \\
\hline 2012 Ramayana & 2 \\
\hline 2013 Ramayana & 3 \\
\hline 2014 Ramayana & 4 \\
\hline
\end{tabular}

yaitu perusahaan yang mencapai tinggat efisiensi dalam 3 pengukuran (Teknis efisiensi, teknis murni efisiensi dan skala). Perusahaan tersebut yaitu PT Asuransi Ramayana dan PT Asuransi Bintang. Laporan Keuangan PT Asuransi Ramayana yang dijadikan DMU (Decision Making Unit) yaitu tahun 2012-2014 mampu mencapai tingkat efisiensi secara optimal dalam 3 pengukuran efisiensi. Selanjutnya PT Asuransi Bintang dimana pada Laporan Keuangan 2013 juga berada pada tingkat efisiensi secara optimal dalam 3 pengukuran. Karena tingkat efisiensinya berada pada titik optimal inilah yang menjadikan kedua perusahaan asuransi syariah menjadi peringkat tertinggi pada kelompok Unit Syariah Perusahaan Asuransi Umum.

Peringkat kelompok selanjutnya yaitu Perusahaan-perusahaan Asuransi Jiwa Syariah dapat dilihat pada tabel berikut:

Tabel 6. Peringkat Perusahaan Asuransi Jiwa Syariah di Indonesia

\begin{tabular}{lc}
\hline \multicolumn{1}{c}{ Nama Perusahaan } & Peringkat \\
\hline 2014 Takaful keluarga & 1 \\
\hline 2012 Takaful keluarga & 2 \\
\hline 2013 Takaful keluarga & 3 \\
\hline
\end{tabular}

Karena pada kelompok Perusahaan Asuransi Jiwa Syariah ini hanya diwakili oleh 1 perusahaan saja yaitu PT Asuransi Jiwa Takaful Keluarga maka peringkat diberikan berdasarkan pada tahun berapa perusahaan tersebut mampu menghasilkan rata-rata tingkat efisiensi paling tinggi dalam 3 pengukuran. Pada tabel tersebut menunjukkan bahwa PT Asuransi Jiwa Takaful Keluarga mengalami tingkat efisiensi tertinggi pada tahun 2014. Salah satu penyebab PT Asuransi Takaful Keluarga di tahun 2014 memiliki skor efisiensi tertinggi yaitu karena pada tahun tersebut Takaful Keluarga sedang berfokus pada keunggulan layanan termasuk TI sehingga banyak efisiensi. Hal ini dijelaskan langsung oleh Direktur Utama PT Asuransi Takaful Keluarga seusai acara tasyakura Milad ke-20 Takaful Keluarga di Jakarta. (Pratiwi, 2014)

Kemudian kelompok terakhir yaitu Kelompok Unit Syariah dari Perusahaan Asuransi Jiwa. Peringkat perusahaan-perusahaan yang berada pada kelompok ini dapat dilihat pada tabel berikut:

Tabel 7. Peringkat Unit Syariah Perusahaan Asuransi Jiwa di Indonesia

\begin{tabular}{lc}
\hline \multicolumn{1}{c}{ Nama Perusahaan } & Peringkat \\
\hline 2012 Allianz Life Indonesia & 1 \\
\hline 2014 Allianz Life Indonesia & 2 \\
\hline 2014 Bringin Jiwa Sejahrera & 3 \\
\hline
\end{tabular}




\begin{tabular}{lc}
\hline 2014 Mega Life & 4 \\
\hline 2012 Prudential Life & 5 \\
\hline 2014 Prudential Life & 6 \\
\hline 2013 Prudential Life & 7 \\
\hline 2013 Allianz Life Indonesia & 8 \\
\hline 2014 Tokio Marine Life & 9 \\
\hline 2012 Bringin Jiwa Sejahrera & 10 \\
\hline
\end{tabular}

Pada tabel di atas menunjukkan bahwa Perusahaan yang berada pada peringkat 10 besar atau memiliki rata-rata tingkat efisiensi tertinggi yaitu terdiri dari 5 perusahaan. Keempat perusahaan tersebut yaitu PT Asuransi Allianz Life Indonesia, PT Prudential Life Assurance, PT Asuransi Bringin Jiwa Sejahtera PT Asuransi Jiwa Mega Life dan PT Tokio Marine Life Insurance. Peringkat 1-5 merupakan peringkat dimana ke-5 DMU (Decision Making Unit) tersebut mencapai tingkat efisiensi yang optimal dalam 3 pengukuran (teknis efisiensi, teknis murni efisiensi dan skala).

Jadi dengan adanya peringkat tersebut setiap perusahaan dapat mengetahui pada tahun keberapa perusahaan memiliki tingkat efisiensi yang paling baik untuk dijadikan referensi dalam pengambilan keputusan penggunaan inputdan memaksimalkan output pada periode selanjutnya. Dan juga perusahaan-perusahaan tersebut dapat dijadikan referensi atau rujukan bagi perusahaan lain untuk dapat meningkatkan skor efisiensi perusahaannya.

\section{SIMPULAN}

Kesimpulan dari penelitian tingkat efisiensi Perusahaan Asuransi Syariah dengan menggunakan metode Data Envelopment Analysis (DEA) selama periode pengamatan 2012-2014 yaitu pada kelompok Perusahaan Asuransi Umum Syariah, 2 perusahaan yang dijadikan sampel tidak ada yang dapat mencapai tingkat efisiensi secara optimal. Sedangkan pada kelompok Unit Syariah Asuransi Umum terdapat 2 perusahaan dari 7 perusahaan yang dijadikan sampel atau sebesar $28.57 \%$ perusahaan yang efisien secara optimal dalam mengelola risiko para peserta asuransi. Pada kelompok Perusahaan Asuransi Jiwa Syariah, 1 perusahaan yang dijadikan sampel dalam tahun pengamatan 2012-2014 tidak ada yang mencapai tingkat efisien secara optimal. Dan yang terakhir pada kelompok Unit Syariah Asuransi Jiwa, dari 12 perusahaan yang dijadikan sampel penelitian terdapat 4 perusahaan yang mampu mencapai tingkat efisien secara optimal atau sebesar $25 \%$ perusahaan yang efisien secara optimal dalam mengelola risiko para peserta asuransi.

Sumber inefisiensi pada Perusahaan Asuransi Syariah di Indonesia terdapat pada 4 variabel yaitu total aset, biaya komisi, kontribusi bruto dan pendapatan investasi. Pada total aset dan biaya komisi diperlukan perbaikan dengan pengurangan sebesar $39.66 \%$ pada variabel tersebut. Pada kontribusi bruto diperlukan perbaikan dengan dilakukannya peningkatan sebesar 1.44\%$165.50 \%$ pada variabel tersebut. Dan variabel yang terakhir yaitu pendapatan 
investasi yang juga memerlukan perbaikan dengan peningkatan sebesar $11.95 \%-195.69 \%$.

\section{DAFTAR PUSTAKA}

Amerika Serikat Pun Kepincut Asuransi Syariah. (2015). Dipetik Oktober 28, 2015, dari Berita Asuransi: http://www.asuransisyariah.asia

Abduh, M., Omar, M. A., \& Tarmizi, R. M. (2012, December). The Performance of Insurance Industry in Malaysia: Islamic vs Conventional Insurance. Journal of Islamic Banking and Finance, Vol.29 No.4.

Akbar, N. (2009, August-December 2). Analisis Efisiensi Organisasi Pengelola Zakat Nasional Dengan Pendekatan Data Envelopment Analysis. Islamic Finance \& Business Review, Vol.4 No.2.

Al-Amri, K. (2015, February 9). Takaful Insurance Efficiency in The GCC Countries. Journal Sultan Qaboos University, Vol.31 No.3,2015 pp.344-353.

Ascarya, \& Yumanita, D. (2008). Comparing The Efficiency Of Islamic Banks In Malaysia and Indonesia. Buletin Ekonomi Moneter dan Perbankan, 99.

Banker, R., Charnes, A., \& Cooper, W. (1984). Some Metodes for Estimating Technical and Scale Inefficiency in Data Envelopment Analysis. Journal Management Science, Vol. 30 No.9.

Charnes, A., Cooper, W., \& Rhodes, E. (1978). Measuring the Efficiency of Decision Making Units, European Journal of Operation Research. European Journal Of Operational Research 2 .

Coelli, T. J., Rao, D. S., O'Donnel, C. J., \& Battese, G. E. (2005). Introduction to Efficiency and Productivity Analysis (Second Edition ed.). Boston: Springer.

Edi Junaedi, N. H. (2009). Fenomena Ekonomi Syari'ah Menurut Akuntan Memahami Prinsip-Prinsip Akuntansi Syariah. Working Paper In Accounting and Finance , 2.

EY. (2014). Global Takaful Insight 2014 Market Update. EY Global Limited.

Farrell, M. (1957). Te Measurement of Productive Efficiency. Jurnal of the Royal Statistical Society, Vol.120, No. 3.

Febrinol, T. S. (2012, September 25). Peran Bank Syariah dalam Mengembangan Usaha Kecil Menengah. Dipetik November 4, 2015, dari Rubrik Kompasiana: http://www.kompasiana.com 
Hassine, M. B., \& Limani, R. (2014). The Impact of Bank Characteristics on the Efficiency: Evidence from MENA Islamic Banks. Journal of Applied Finance \& Banking, Vol. 4 No.2, 237-253.

IR. (2014, February 26). (IR, Penyunting) Dipetik January 17, 2016, dari Asuransi Syariah: http://www.asuransi-indonesia.net/

Karim Consulting Indonesia. (2015). Islamic Finance Outlook 2015. Karim Consulting Indonesia.

Karim, A. (2007). Ekonomi Mikro Islam. Jakarta: Raja Grafindo Persada.

Khan, A., \& Noreen, U. (2014, May). Efficiency Measure of Insurance vs Takaful Firms Using DEA Approach: A Case of Pakistan. Journal Islamic Economic Studies, Vol. 22 No.1, May 2014 (139-158).

Kusumawardhani, A. (2015, July 29). AASI: Asuransi Syariah Tahun Ini Tumbuh Di Atas 25\%. Dipetik November 4, 2015, dari Asuransi: http://www.finansial.bisnis.com

Mansor, S. A., \& Radam, A. (2000). Productivity and Efficiency Performance of Malaysian Life Insurance Industry. Jurnal Ekonomi Malaysia, 34, 93-105.

Miniaoui, H., \& Chaibi, A. (2014). Technical Efficiency of Takaful Industry: A Comparative Study of Malaysia and GCC Countries. Working Paper Series IPAG Bussiness School.

Muharam, H., \& Pusvitasari, R. (2007). Analisis Perbandingan Efisiensi Bank Syariah di Indonesia Dengan Metode Data Envelopment Analysis. Jurnal Ekonomi dan Bisnis Islam, Vol.II No.3, 86-87.

Nugroho, S. S. (1995). Analisis DEA dan Pengukuran Efisiensi Mdderk. Jurnal Kelola Gajah Mada Business News No.8/IV.

Otoritas Jasa Keuangan. (2014). Statistik Perasuransian 2013. Jakarta: Otoritas Jasa Keuangan (OJK).

Pratiwi, F. (2014, September 22). Takaful Keluarga Fokus Tingkatkan SDM dan TI. (I. Kelana, Penyunting) Dipetik February 4, 2016, dari Republika Online: http://www.republika.co.id/

Rahman, M. A. (2013). Comparative Study on the Efficiency of Bangladeshi Conventional and Islamic Life Insurance Industry: A Non-Parametric Approach. Journal Asian Business Review, Vol.2 No.3/2013(5).

Rai, I. G. (2008). Audit Kinerja pada Sektor Publik. Jakarta: Salemba Empat.

Shafique, M. N., Ahmad, N., Ahmad, H., \& Adil, M. Y. (2015). A Comparative Study Of The Efficiency Of Takaful And Conventional Insurance In Pakistan. International Journal Of Accounting Research, Vol.2 No.5. 
Wibowo, S., \& Supriadi, D. (2013). Ekonomi Mikro Islam. Bandung: CV Pustaka Ceria. 
